\title{
Assessment of some important fertility parameters related to different land use systems in the humid forest zone of southern Cameroon
}

\author{
BIRANG À MADONG *, Victor AGOUMÉ and BIDZANGA NOMO \\ Institut de la Recherche Agricole pour le Développement,P.O. Box 2067, Messa-Yaoundé, Cameroon. \\ *Corresponding author,E-mail: crbirang@yahoo.com,vagoume@yahoo.com andn_bidzanga@yahoo.fr
} Tel: (237) 996220 13, Fax: (237) 22233538

\begin{abstract}
A field study was carried out in 1999 and 2000 in the village of Akok $180 \mathrm{~km}$ south of Yaoundé in the humid forest zone of southern Cameroon to assess changes in particle size distribution and soil chemical properties related to five different land-use systems namely: a secondary forest, a young forest, a cocoa farm, a Chromolaena fallow and a mixed food crop field. The results showed that land-use systems significantly affect the soil particle distribution and the highest proportions of sand and silt fractions were found in soils of young forests, the highest clay content was found under cocoa farms $(\mathrm{P}<0.0001)$. Soil $\mathrm{pH}_{\mathrm{H} 2 \mathrm{O}}$, exchangeable $\mathrm{Ca}$ and $\mathrm{Mg}, \mathrm{Al}$ saturation and ECEC in the first, second and third $10 \mathrm{~cm}$ layers varied significantly with land-use systems $(\mathrm{P}<0.0001)$; organic carbon in the first and the second $10 \mathrm{~cm}$ layers significantly differ with the landuse systems $(\mathrm{P}=0.0115)$; and available $\mathrm{P}$ in the second and third $10 \mathrm{~cm}$ layers varied significantly with land-use systems $(\mathrm{P}<0.0007)$. Moreover cocoa farms had the highest $\mathrm{pH}$, the lowest $\mathrm{Al}$ saturation, the highest soil $\mathrm{Ca}$, $\mathrm{Mg}, \mathrm{ECEC}$ and $\mathrm{P}$ contents compared to the other land-use systems. Based on their $\mathrm{pH}$ level and their high base saturation levels, soils of cocoa farms seem to present a higher fertility status than those of the rest of land-use systems. It is assumed that permanent vegetation coverage and/or exposure to heavy rains of the soils, disturbances due to land preparation, organic matter supplied by the vegetation, nutrient cycling, nutrient restitution and nutrient uptake could be differentiation factors.
\end{abstract}

(C) 2009 International Formulae Group. All rights reserved.

Key words: Saturation, ECEC, particle size distribution, nutrient cycling, requirement.

\section{INTRODUCTION}

In the rain forest zone of southern Cameroon, shifting cultivation (mixed food fields) and perennial plantations (cocoa plantation) are the main land use systems practiced by small-scale farmers to meet food needs and provide small incomes. The traditional shifting cultivation system involves the manual clearing of a small area of natural vegetation (forest, bush, woody savanna or grassland) and leaving the land under fallow for a long period after a few cropping years to allow soil fertility restoration (ASB, 2000). According to Yemefack (2005), the analysis of soil characteristic changes with the cropping systems may follow two phases: (i) clearing and burning of the vegetation biomass during which derived ash causes rapid changes in soil properties and (ii) the slower changes in soil properties during the cropping period and subsequent fallowing or perennial plantations. Lal (1996) and Shepherd et al. (2000) reported that land-use in tropical ecosystems could significantly affect soil properties. Shipper and Sparling (2000), Birang et al. (2003) indicated that those modifications were biologically and chemically more rapid than physically. Tchienkoua et al. (2004) found that land use conversion from semi-permanent mixed food crop system to Eucalyptus and tea plantation in the highlands of West Cameroon led to 
significant organic matter build up in the soil system; the Eucalyptus system induced an enhanced cycling of macronutrients $(\mathrm{Ca}$ and $\mathrm{Mg}$ ) and immobilization of large amount of $\mathrm{P}$ and $\mathrm{K}$.

Research on soil characteristics changes is important to design soil fertility options for better land-use. This study, evaluates the effects of land-use systems on the following soil properties: particle size distribution (sand, clay, silt), $\mathrm{pH}$, organic carbon, total nitrogen, $\mathrm{C} / \mathrm{N}$ ratio, available $\mathrm{P}$, exchangeable bases $(\mathrm{Ca}, \mathrm{Mg}, \mathrm{K})$, exchangeable Al, ECEC, base saturation and $\mathrm{Al}$ saturation under the following land use system: soils cropped under food crops, perennial crops, fallow, young and secondary forests of Akok village in Cameroon in order to propose management options that could maintain or improve their fertility status.

\section{MATERIALS AND METHODS}

Site location and land-use systems selected

The geographical coordinates of Akok village are: $11^{\circ} 14^{\prime} \mathrm{E}$ longitude, $2^{\circ} 44^{\prime} \mathrm{N}$ latitude and $585 \mathrm{~m}$ altitude (Figure 1). The climate is humid tropical, with annual rainfall range of $1350-1900 \mathrm{~mm}$ and air temperature of $22-26{ }^{\circ} \mathrm{C}$. The natural vegetation in the village is a dense humid semi-deciduous tropical forest. Most of the upland soils belong to the group of Kandiudox (USDA, 1986). The area is characterized by low level of deforestation and low level of land-use intensity. The 5 most common land-use systems (LUS) of the region, are: a groundnut/maize/cassava annual inter-crop field (crop), Chromolaena odorata dominated fallow (4-5 years old, Chro), a young forest fallow (12-15 years, Yfor), a shaded (35 years old) cocoa plantation (Coco) and a secondary forest ( $>30$ years, Sfor). The experiment was laid out in a randomized complete block design including 5 land-use systems as treatments, 3 soil depths $(0-10 \mathrm{~cm}, 10-20$ $\mathrm{cm}$ and $20-30 \mathrm{~cm})$ and 5 replicates.

\section{Soil sampling and analyses for physical properties assessment}

Soils Samples were taken for physical properties determination in each land use from each of the five mini pits $(50 \times 50 \times 30 \mathrm{~cm}$ (LxWxD) along a $100 \mathrm{~m}$ transect. From each mini pit, bulk soil samples were horizontally collected at the walls of the mini-pit at 0-10 and 10-20 and 20-30 cm from three $100 \mathrm{~cm}^{3}$ soil cores and used, air-dried, ground to pass a 2-mm mesh sieve for determining soil textural classes. Soils particle sizes were determined by the pipette method (Gee and Bauder, 1986).

\section{Soil sampling and analyses for chemical determinations}

Between May and August of each year, prior to establishing the cropped plots, five mini-pits of 50x50x30 cm (L x W x D) were dug out along a $100 \mathrm{~m}$ transect in each fallow. Soil samples were taken from these mini-pits at three different depths $(0-10 \mathrm{~cm}, 10-20 \mathrm{~cm}$ and $20-30 \mathrm{~cm}$ ) for chemical analysis. All the samples were oven dried at $65{ }^{\circ} \mathrm{C}$ for 48 hours, then ground to pass through a $0.5 \mathrm{~mm}$ mesh size sieve and analysed for $\mathrm{pH}$, total $\mathrm{N}$, organic $\mathrm{C}$, available $\mathrm{P}$ and exchangeable $\mathrm{Ca}$, $\mathrm{Mg}, \mathrm{K}$ and $\mathrm{Al}$.

Soil $\mathrm{pH}$ was determined in a water suspension at a 2:5 soil/ water ratio. Exchangeable $\mathrm{Ca}^{2+}, \mathrm{Mg}^{2+}, \mathrm{K}^{+}, \mathrm{Al}^{3+}$ and available $\mathrm{P}$ were extracted by the Mehlich-3 procedure (Mehlich, 1984). Exchangeable cations were determined by atomic absorption spectrophotometry and available $\mathrm{P}$ by the Malachite green colorimetric procedure (Motomizu et al., 1983). Organic C was determined by chromic acid digestion and spectrophotometry (Hearnes, 1984). Total N was determined using the Kjeldahl method for digestion and ammonium electrode determination (Bremmer and Tabatabai, 1972; Bremmer, 1982).

\section{Statistical and numerical analyses}

Analyses of variance were conducted using the General Linear Model (GLM) procedure of the Statistical Analysis System (SAS, 1999). Statistical comparisons of landuse systems were performed by analysis of variance. The means were separated using the Student-Newman-Keuls Test.

\section{RESULTS \\ Soil characteristics}

The results on soil properties of Akok village are presented in Table 1 . In overall average from the three layers, this soil fell in the sandy clay soil class according to the triangle methods of soil classification (sand $41 \%$, clay $51 \%$ and silt $8 \%$ ). The topsoil (0-10 $\mathrm{cm})$ features as a sandy clay and the subsoil 


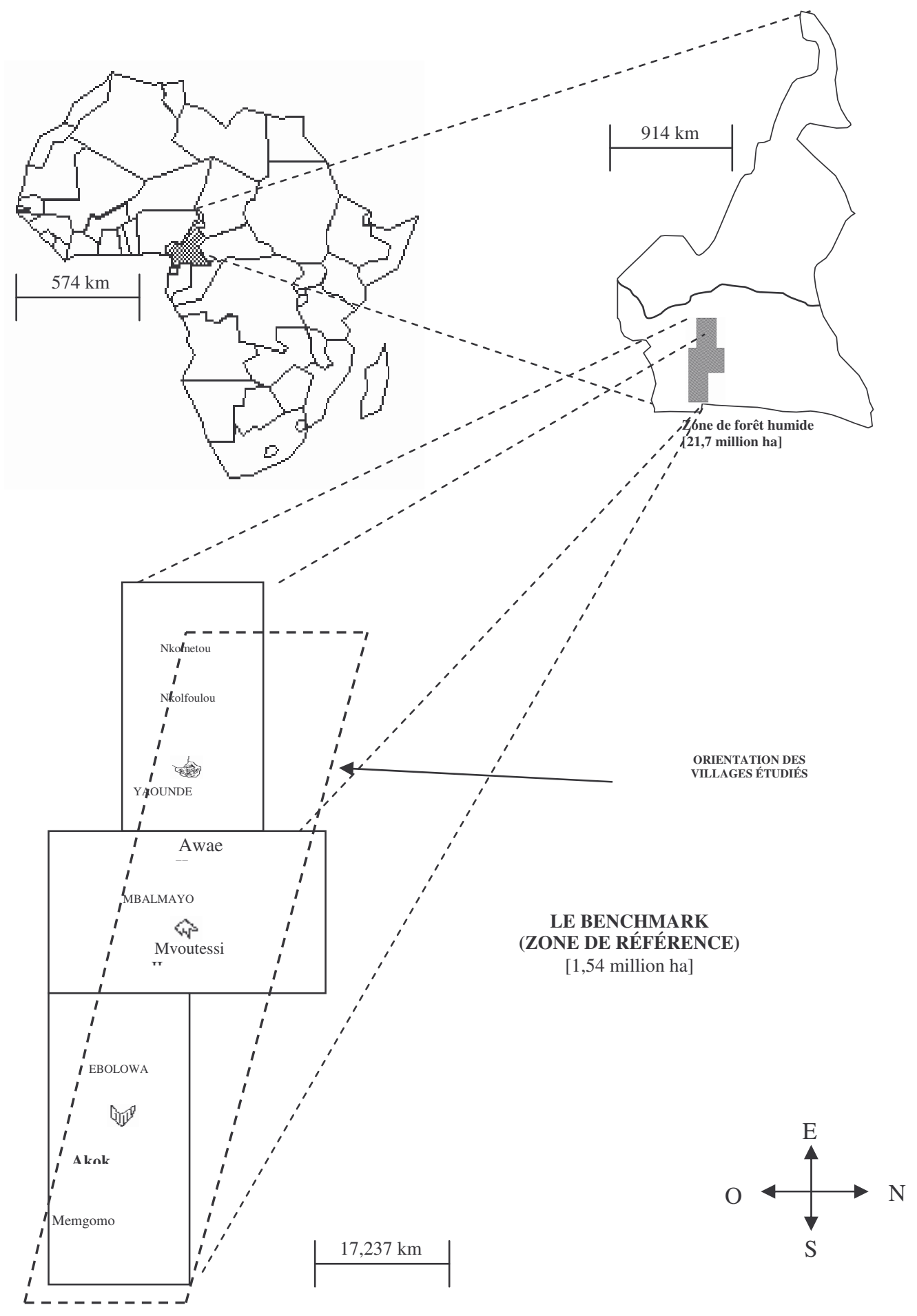

Figure 1: Study area: the forest margins Benchmark area in Southern Cameroon. (Source: Thesis Birang Madong, Wageningen University, 2004). 
Table 1: Means and probabilities of soil characteristics of Akok village in Southern Cameroon.

\begin{tabular}{|c|c|c|c|c|c|}
\hline \multirow[t]{2}{*}{ Characteristics } & \multicolumn{5}{|c|}{ Soil depth } \\
\hline & $0-10 \mathrm{~cm}$ & $10-20 \mathrm{~cm}$ & $20-30 \mathrm{~cm}$ & $\mathbf{P}^{\$}$ & $\mathbf{L S D}_{0.05}$ \\
\hline Sand $(\%)$ & 47.45 & 39.27 & 36.18 & $<0.0001$ & 2.22 \\
\hline Clay (\%) & 43.27 & 53.63 & 56.07 & $<0.0001$ & 2.61 \\
\hline Silt $(\%)$ & 9.28 & 7.10 & 7.75 & 0.0003 & 1.05 \\
\hline $\mathrm{pH}_{\mathrm{H} 2 \mathrm{O}}(2: 5)$ & 4.54 & 4.53 & 4.60 & 0.5072 & \\
\hline $\mathrm{OC}(\%)$ & 2.18 & 1.11 & 0.91 & $<0.0001$ & 0.20 \\
\hline Total N (\%) & 0.17 & 0.09 & 0.07 & $<0.0001$ & 0.02 \\
\hline $\mathrm{C} / \mathrm{N}$ & 13.01 & 12.50 & 12.71 & 0.6040 & \\
\hline Available P (ppm) & 6.21 & 2.07 & 1.52 & $<0.0001$ & 1.27 \\
\hline Exchangeable Ca (me/100g) & 1.26 & 0.36 & 0.32 & $<0.0001$ & 0.41 \\
\hline Exchangeable $\mathrm{Mg}$ (me/100g) & 0.52 & 0.16 & 0.09 & $<0.0001$ & 0.13 \\
\hline Exchangeable K(me/100g) & 0.11 & 0.05 & 0.04 & $<0.0001$ & 0.01 \\
\hline Exchangeable Al (me/100g) & 1.69 & 2.09 & 2.17 & 0.0014 & 0.34 \\
\hline $\mathrm{ECEC}(\mathrm{me} / 100 \mathrm{~g})$ & 3.57 & 2.65 & 2.62 & 0.0007 & 0.55 \\
\hline Base saturation (\%) & 49.42 & 27.06 & 24.03 & $<0.0001$ & 7.78 \\
\hline Al saturation $(\%)$ & 50.58 & 72.94 & 75.97 & $<0.0001$ & 7.78 \\
\hline
\end{tabular}

(10-30 $\mathrm{cm})$ as a clay. Overall soil $\mathrm{pH}_{\mathrm{H} 2 \mathrm{O}}$ was below 5, with no significant difference between layers. Organic carbon and total $\mathrm{N}$ decreased significantly with soil depth but the $\mathrm{C} / \mathrm{N}$ ratio did not follow that trend. Available $\mathrm{P}$ and exchangeable cations decreased significantly with depth while $\mathrm{Al}$ in the opposite increased significantly. ECEC decreased significantly with depth.

\section{Effect of land-use systems on soil particle size distribution}

Land-use systems significantly affected the sand and the clay fractions of the soils (Figure 2.). In the top layer $(0-10 \mathrm{~cm})$, the proportion of sand was greater in soils of Yfor than in soils of the other land-use systems and the clay percentage followed the reverse sequence. In the medium layer $(10-20 \mathrm{~cm})$, the sand fraction was in soils as Yfor $=$ Sfor= Chro $=$ Crop and Sfor $=\mathrm{Chro}=\mathrm{Crop}=\mathrm{Coco}$ and Yfor $>$ Coco, and the clay fraction was as follows: $\mathrm{Coco}=\mathrm{Crop}=\mathrm{Chro}=\mathrm{Sfor}$ and $\mathrm{Crop}=$ Chro $=$ Sfor $=$ Y for and Coco $>$ Yfor. In the third layer $(20-30 \mathrm{~cm})$, the sand fraction was greater in soils as $\mathrm{Yfor}>\mathrm{Chro}=\mathrm{Crop}=$ Sfor $>$ Coco and the clay fraction followed the reverse sequence. The silt fraction differred only for the second and third soil layer as respectively follows: Sfor=Yfor and
Yfor $=\mathrm{Crop}=\mathrm{Chro}=\mathrm{Coco}$ and Sfor $>\mathrm{Crop}=$ Chro $=$ Coco in the $10-20 \mathrm{~cm}$, Yfor $>$ Sfor $>$ $\mathrm{Crop}=\mathrm{Chro}=\mathrm{Coco}$ in the $20-30 \mathrm{~cm}$.

Effect of land-use systems on soil chemical properties

All the measured soil chemical properties varied with land-use systems (Table 2, Figure 3).

Coco plantation contained significantly more exchangeable bases and presented a significantly greatest $\mathrm{pH}$ (Figure 3) than all the other land-use systems while in the opposite, secondary forest exhibited more available $\mathrm{Al}$ (Al saturation) and lowest $\mathrm{pH}$ values in all three layers. Sfor contained significantly more Org C and Tot $\mathrm{N}$ than Chro in first two layers. Coco plantation significantly contained more available $\mathrm{P}$ than all the other land use systems and in the three layers.

\section{DISCUSSION}

The soils of Akok were mostly sandy clay with a high fraction of clay. This could derive from the dissolution and leaching of silica due to high rainfall in the site whose pattern is bi modal with pics in May and October (Tchienkoua, 2005). The particle 


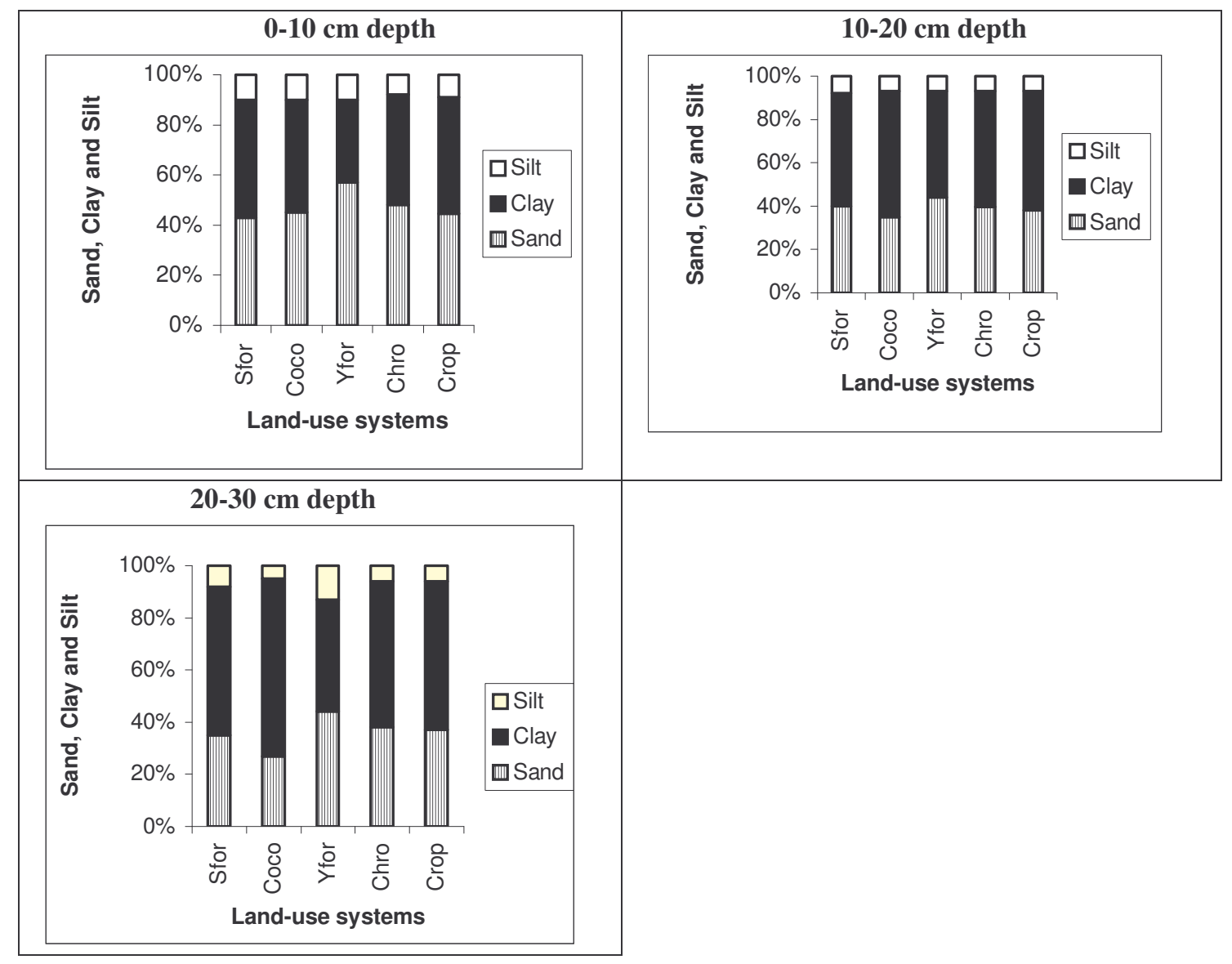

Figure 2: Effect of land-use systems on soil particles size distribution.

size distribution might also reflect the texture of the area parent material which is granite (Tchienkoua, 2005). The sand and silt percentages decreased with the depth whereas the opposite situation was found for the clay. This hints the possibility of clay translocation in soil profile. Clay accumulation in the subsoil could result in reduced porosity, increased water retention and reduced drainage.

Our result showed a significant difference between layers for the silt fraction. But Voundi Nkana and Tonye (2002) did not find any changes in silt fraction distribution, may be because they dealt with $0-20 \mathrm{~cm}$ soil layer while this study dealt with $0-10 \mathrm{~cm}$ soil layer.

Lal (1996) and Voundi Nkana and Tonye (2002) found similarly that continuous cropping and intensive land-use both affect the particle size distribution and these changes depend on cultivation duration. Shepherd et al. (2000) indicated no effect of land-use systems on soil particle size distribution. The similarity or differences between results can be attributed to differences between experiments conditions. Cocoa farms had the highest clay percentage (58\%). But as the overall soil texture must take into account both soil organic carbon and $\mathrm{Ca}$ contents (Duchaufour, 1960), soils under cocoa farms might have the highest fertility status since they keep the first ranking for organic carbon and calcium contents.

According to the guidelines elaborated by Landon (1991) for tropical soils, high, medium and low Org $\mathrm{C}$ content correspond to: $>10,4-10$ and <4\%; for Org $\mathrm{N}$ to: $>0.5,0.2$ -0.5 and $<0.2 \%$ and for P to: $0-5,5-10$ and $10-15$ respectively. Therefore in our study, organic carbon and total nitrogen contents 
Table 2: Effect of land-use systems on soil chemical properties in Akok in southern Cameroon.

\begin{tabular}{|c|c|c|c|c|c|c|c|c|c|}
\hline $\begin{array}{l}\text { Land- } \\
\text { use } \\
\text { System }\end{array}$ & $\begin{array}{l}\mathrm{pH}_{\mathrm{H} 2 \mathrm{O}} \\
(1: 2.5)\end{array}$ & $\begin{array}{c}\text { Org. } \\
\text { C } \\
(\%)\end{array}$ & $\begin{array}{c}\text { Tot. } \mathbf{N} \\
(\%)\end{array}$ & $\mathrm{C} / \mathrm{N}$ & $\begin{array}{c}\text { Available } \\
\text { P } \\
(\mathrm{ppm})\end{array}$ & $\begin{array}{c}\text { Ca } \\
(\mathrm{me} / 100 \mathrm{~g})\end{array}$ & $\begin{array}{c}\text { Mg } \\
(\mathrm{me} / 100 \mathrm{~g})\end{array}$ & $\begin{array}{c}\mathbf{K} \\
(\mathrm{me} / 100 \mathrm{~g})\end{array}$ & $\begin{array}{c}\text { ECEC } \\
(\mathrm{me} / 100 \mathrm{~g})\end{array}$ \\
\hline & & & & $\begin{array}{l}0-10 \mathrm{~cm} \\
\text { depth }\end{array}$ & & & & & \\
\hline Sfor & $3.80 \mathrm{c}$ & $2.65 a$ & $0.13 \mathrm{a}$ & $12.68 \mathrm{ba}$ & $3.43 \mathrm{~b}$ & $0.14 b$ & $0.17 \mathrm{c}$ & $0.11 \mathrm{ba}$ & $4.22 b$ \\
\hline Coco & $5.50 \mathrm{a}$ & $2.33 \mathrm{ba}$ & $0.11 b$ & $12.32 \mathrm{ba}$ & $5.76 a$ & $3.97 \mathrm{a}$ & $1.22 \mathrm{a}$ & $0.07 b$ & $5.35 \mathrm{a}$ \\
\hline Yfor & $4.51 \mathrm{~b}$ & $2.32 \mathrm{ba}$ & $0.11 b$ & $14.88 \mathrm{a}$ & $4.31 \mathrm{~b}$ & $1.13 \mathrm{~b}$ & $0.63 b$ & $0.13 \mathrm{a}$ & $2.89 \mathrm{c}$ \\
\hline Chro & $4.56 \mathrm{~b}$ & $1.68 \mathrm{~b}$ & $0.10 \mathrm{~b}$ & $11.85 \mathrm{~b}$ & $1.84 \mathrm{c}$ & $0.63 b$ & $0.33 b$ & $0.13 \mathrm{a}$ & $2.51 \mathrm{c}$ \\
\hline Crop & $4.51 b$ & $1.89 \mathrm{ba}$ & 0.10 & $13.18 \mathrm{ba}$ & $1.61 \mathrm{c}$ & $0.97 b$ & $0.39 b$ & $0.10 \mathrm{ba}$ & $3.26 \mathrm{cb}$ \\
\hline \multirow[t]{2}{*}{$\mathbf{P}$} & $<0.0001$ & 0.0161 & 0.0071 & 0.0403 & $<0.0001$ & $<0.0001$ & 0.0001 & 0.0066 & 0.0011 \\
\hline & & & & $\begin{array}{c}10-20 \mathrm{~cm} \\
\text { depth }\end{array}$ & & & & & \\
\hline Sfor & $4.21 \mathrm{c}$ & $1.40 \mathrm{a}$ & $0.10 \mathrm{a}$ & $13.37 \mathrm{a}$ & $1.40 \mathrm{~b}$ & $0.06 \mathrm{~b}$ & $0.07 \mathrm{~b}$ & $0.06 \mathrm{a}$ & $3.26 \mathrm{a}$ \\
\hline Coco & $4.98 \mathrm{a}$ & $0.92 b$ & $0.08 \mathrm{~b}$ & $11.47 \mathrm{a}$ & $5.52 \mathrm{a}$ & $1.00 \mathrm{a}$ & $0.26 a$ & $0.04 \mathrm{a}$ & $0.31 \mathrm{~d}$ \\
\hline Yfor & $4.46 \mathrm{~b}$ & $1.00 \mathrm{~b}$ & $0.08 \mathrm{~b}$ & $11.85 \mathrm{a}$ & $1.89 \mathrm{~b}$ & $0.34 \mathrm{~b}$ & $0.27 \mathrm{a}$ & $0.05 \mathrm{a}$ & $2.18 \mathrm{c}$ \\
\hline Chro & $4.55 b$ & $1.05 \mathrm{~b}$ & $0.08 \mathrm{~b}$ & $12.70 \mathrm{a}$ & $0.74 b$ & $0.11 b$ & $0.06 \mathrm{~b}$ & $0.06 \mathrm{a}$ & $2.18 \mathrm{c}$ \\
\hline Crop & $4.39 b$ & $1.21 \mathrm{ba}$ & $0.09 \mathrm{ba}$ & $13.29 \mathrm{a}$ & $0.65 b$ & $0.21 b$ & $0.11 \mathrm{~b}$ & $0.07 \mathrm{a}$ & $2.75 b$ \\
\hline \multirow[t]{2}{*}{$\mathbf{P}$} & $<0.0001$ & 0.0115 & 0.0322 & 0.2232 & 0.0007 & $<0.0001$ & 0.0051 & 0.2105 & $<0.0001$ \\
\hline & & & & $\begin{array}{c}20-30 \mathrm{~cm} \\
\text { depth }\end{array}$ & & & & & \\
\hline Sfor & $4.35 \mathrm{c}$ & $1.01 \mathrm{a}$ & $0.07 \mathrm{a}$ & $0.08 \mathrm{a}$ & $0.48 b$ & $0.03 \mathrm{c}$ & $0.05 \mathrm{c}$ & $0.04 \mathrm{ba}$ & $3.10 \mathrm{a}$ \\
\hline Coco & $5.07 \mathrm{a}$ & $0.82 \mathrm{a}$ & $0.07 \mathrm{a}$ & $0.08 \mathrm{a}$ & $5.75 a$ & $0.95 \mathrm{a}$ & $0.15 b$ & $0.01 \mathrm{~b}$ & $0.34 \mathrm{c}$ \\
\hline Yfor & $4.58 \mathrm{~b}$ & $0.85 a$ & $0.07 \mathrm{a}$ & $0.07 \mathrm{a}$ & $0.50 \mathrm{~b}$ & $0.46 \mathrm{~b}$ & $0.24 \mathrm{a}$ & $0.04 \mathrm{ba}$ & $2.99 \mathrm{a}$ \\
\hline Chro & $4.55 \mathrm{~b}$ & $0.82 \mathrm{a}$ & $0.07 \mathrm{a}$ & $0.07 \mathrm{a}$ & $0.01 \mathrm{~b}$ & $0.08 \mathrm{c}$ & $0.05 \mathrm{c}$ & $0.05 \mathrm{ba}$ & $2.33 \mathrm{~b}$ \\
\hline Crop & $4.42 \mathrm{cb}$ & $1.02 \mathrm{a}$ & $0.08 \mathrm{a}$ & $0.06 \mathrm{a}$ & $0.24 b$ & $0.17 \mathrm{c}$ & $0.08 \mathrm{cb}$ & $0.06 \mathrm{a}$ & $2.57 \mathrm{ba}$ \\
\hline $\mathbf{P}$ & $<0.0001$ & 0.0662 & 0.3370 & 0.3370 & $<0.0001$ & $<0.0001$ & 0.0010 & 0.0485 & $<0.0001$ \\
\hline
\end{tabular}

were low. The low content of available $\mathrm{P}(<5$ $\mathrm{ppm})$ indicated its deficiency in the soils. Exchangeable $\mathrm{Ca}, \mathrm{Mg}$ and $\mathrm{K}$ were low $(<4$ $\mathrm{me} / 100 \mathrm{~g}$ for $\mathrm{Ca},<0.5 \mathrm{me} / 100 \mathrm{~g}$ for $\mathrm{Mg}$ and $<0.2 \mathrm{me} / 100 \mathrm{~g}$ for $\mathrm{K}$ ), showing that these soils are impoverished with respect to basic cations. Due to the strong acidity $(\mathrm{pH}<5)$, these soils contained $\mathrm{Al}$ in the exchangeable form. The very low ECEC derived from the low $\mathrm{pH}$ and reminded that the adsorption capacity of these soils was pH-dependent regulated by the sesquioxides. There is creation of negative sites on the adsorption complex by increasing the $\mathrm{pH}$ via the deprotonation processes. Menzies and Gillman (1997), and Voundi Nkana et al. (1997) justified this low and variable character of the CEC or ECEC within the cameroonian humid forest zone by the domination of low -activity components such as kaolinite, $\mathrm{Fe}$ and $\mathrm{Al}$ (hydr-) oxides in these soils. According to these authors the latest are due to higher degree of weathering of rock's constituent minerals. The parent material (granite) is no longer weatherable, that means that it is full of minerals of low activity and its contribution to the CEC is very low. Thus the charge of these soils is highly organic matter dependent. In such soils, a large part of the plant nutrients and about $90 \%$ of the capacity of the soil nutrient retention depends on soil organic matter (Kauffmann et al., 1998). Buol et al. (1975) noted that soils with ECEC of 4 $\mathrm{me} / 100 \mathrm{~g}$ or less had limited ability to retain nutrient cations. The base saturation was less than $35 \%$ while the $\mathrm{Al}$ saturation was greater than $65 \%$. Sanchez et al. (1982) defined two important thresholds values : soils with more than $10 \% \mathrm{Al}$ saturation present acidity problems while soils with more than $60 \% \mathrm{Al}$ saturation exhibit Al toxicity. Base on this findings we can state that acidity problems will occur in the topsoil and $\mathrm{Al}$ toxicity problems in the subsoil.

Statistically, the three depths significantly differed for most of soil properties except for $\mathrm{pH}$ and $\mathrm{C} / \mathrm{N}$ ratio. The organic carbon, total nitrogen, available $\mathrm{P}$, 


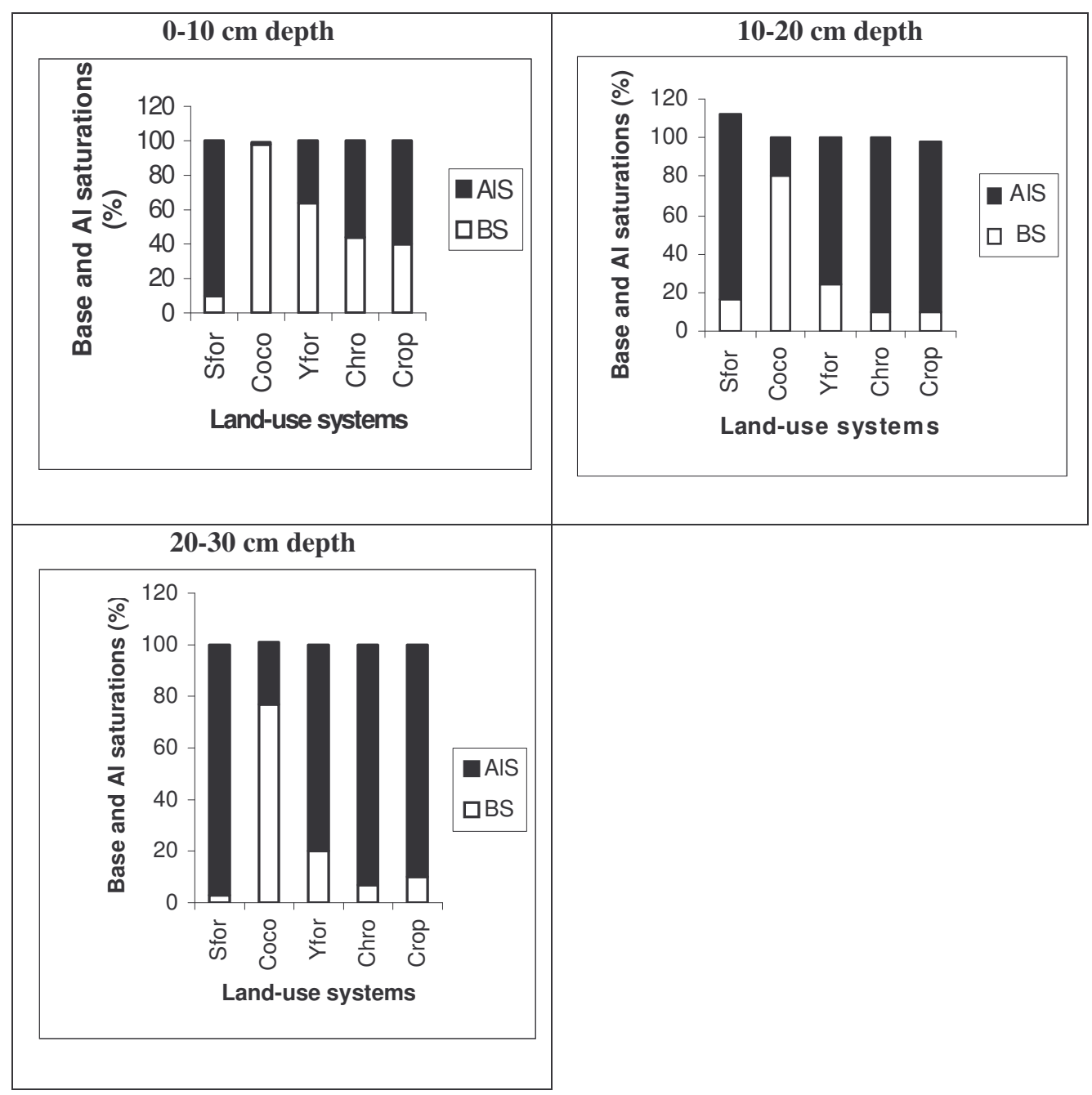

Figure 3: Effect of land-use systems on base saturation (BS) and Al saturation (Als).

exchangeable $\mathrm{Ca}, \mathrm{Mg}$ and $\mathrm{K}$ were higher in the $0-10 \mathrm{~cm}$ layer than in the two subsequent $10 \mathrm{~cm}$ layers. The relative richness of the top $10 \mathrm{~cm}$ layer could be attributed to the regular restitution of $\mathrm{N}, \mathrm{P}$ and basic nutrients at the soil surface via decomposition or burning of plant residues or biomass (Dabin, 1984). The limited amount of exchangeable $\mathrm{Al}$ in the topsoil might be due to its complexation by a good cement formed by the complex organic matter-clay-calcium in this layer, providing thus the soil with a stable structure (Duchauffour, 1960) .

Thus, soils under cocoa farms presented the highest fertility level compared to those of secondary forests because of their higher clay percentage, $\mathrm{pH}, \mathrm{Ca}, \mathrm{Mg}$, available $\mathrm{P}$ and lowest $\mathrm{Al}$ saturation .

Although in another soil type (Typic Kandiudult) with similar land-use systems, Voundi Nkana et al. (2002) obtained different results in the chemical status among land-use systems. But in another study, Kanmegne et al. (2004) found that cocoa farms were the only land-use to have a positive nutrients balance among the studied land-use systems. The highest soil fertility status (higher soil $\mathrm{pH}$, higher available $\mathrm{P}$, higher $\mathrm{Ca}$ content, lower exchangeable $\mathrm{Al}$ and $\mathrm{Al}$ saturation, higher clay percentage) in cocoa farms might be due to the fact that the cycles of $\mathrm{N}$ and $\mathrm{S}$ nutrients issued from the mineralization of 
organic matter were not washed out of the system.

\section{Differentiation Factors}

Under secondary forests as under cocoa farms, soil erosion was low and there was no difference in particle size distribution which were entirely dominated by the clay fraction as clay class in all the three $10 \mathrm{~cm}$ layers (Figure 2). Soil fertility depends on the quantity of organic matter supplied by the natural vegetation and the nutrient cycling (Juo and Manu, 1996). Important changes could therefore occur in base and $\mathrm{Al}$ saturation, and in soil nutrient levels (Table 2, Figure 3). For food crop fields, a significant benefit of slash and burn is the rapid release of nutrients from the ash to the soil (Jordan, 1985 ; Tulaphitak et al., 1985). Burning and cultivation lead to the destruction and rapid decomposition of soil organic matter and reduce the contribution of organic and microbial processes to nutrient cycling (Juo and Manu, 1996). In addition, cocoa farms are established on relatively more fertile soils (Leplaideur, 1985). Chromolaena fallows and food crop fields had similar particle size distribution (Figure 2). However, the fertility status depends on the inevitable loss of soil nutrients in crop (plant material) harvest and additional losses by leaching and runoff.

\section{Consequences for Agricultural Development}

Secondary forest conversion to other land-use systems resulted in less $\mathrm{Al}$ saturation and more nutrients in cocoa farms, and in less acidity and more nutrients in young forests, chromolaena fallows and food crop fields. There was a decrease in organic carbon, exchangeable $\mathrm{Al}$ and an increase in soil $\mathrm{pH}$ (Table 2). Constraints for agricultural development remain the low level of plant nutrients, a low adsorption capacity, the soil acidity and the toxicity caused by high exchangeable Al levels. These conditions are related to the nature of the soils of the rainforest zone. The combination of these nutrient constraints with a very high leaching due to heavy rains, nutrients removal with harvested crops (or plant material) and other losses from the system could result in serious soil degradation. Severely degraded soils do not support any vegetation and hence the land has to be abandoned or taken out of production. This affects the long-term sustainability of intensive production; even the potential benefits of genetically improved varieties cannot be realized (Voundi Nkana and Tonye, 2002 ).

\section{Management options}

Improving and maintaining soil productivity include erosion control, liming and fertilizer application. Residues from harvests must be used to cover the soil surface in order to minimize the evaporation and the effects of erosion specially in food crop fields. For nutrients that persist in the soil such as $\mathrm{P}$, $\mathrm{Mg}$ and $\mathrm{K}$, commercial fertilizers can compensate for nutrients taken up or lost by runoff and leaching. For mobile nutrients like $\mathrm{N}$, because uptake and runoff and/or leaching can be immediate, adding commercial fertilizers is not an option.

Between $0.43 \mathrm{t}$ and $5.60 \mathrm{t} \mathrm{CaCO}_{3} \mathrm{ha}^{-1}$ (or 0.24 to $3.14 \mathrm{t} \mathrm{CaO} \mathrm{ha}^{-1}$ ) must be applied to increase the soil $\mathrm{pH}$ and eliminate $\mathrm{Al}$ toxicity (Kamprath, 1970). Phosphorus additions must take into accounts both the adsorption capacity and $\mathrm{P}$ requirements of the soil (Menzies and Gillman, 1997). Phosphorus requirements were calculated by using the relationship established by Menzies and Gillman (1997) for various humid forest zone of Cameroon.

Basic cations must be applied in proportion to achieve an ideal soil complex. According to Liebbhardt (1981), the ideal is to have the exchange complex saturated with $65 \% \mathrm{Ca}, 10 \% \mathrm{Mg}$ and 5 per cent $\mathrm{K}$, But fluctuations between 65 and $85 \% \mathrm{Ca}, 6$ and $12 \% \mathrm{Mg}$ and 2 and $5 \% \mathrm{~K}$ do not affect the production capacity of the soil. Except for secondary forests for $\mathrm{Mg}$ and $\mathrm{K}$, and cocoa farms for $\mathrm{K}(2 \% \mathrm{~K}, 3 \% \mathrm{Mg}$, and $2 \% \mathrm{~K}$ saturation), calculations showed that the $\mathrm{Mg}$ and $\mathrm{K}$ saturation are almost within the acceptable range $(8-21 \% \mathrm{Mg}$ and $3-4 \% \mathrm{~K})$. However, Ca saturation (3-71\%) was lower than those required. Therefore, $\mathrm{Ca}$ must be added to the soil through liming; and $\mathrm{K}$ should be added to the soil as well as $\mathrm{K}$ soil content situated at the extreme lower limit.

Primary forests on strongly acid and leached soils, depend on internal cycling to meet their mineral requirements (Juo and Manu, 1996) and do not need nutrient management. Liming and $\mathrm{P}$ fertilization appeared therefore as the first and the most 
important operations required for productivity improvement in crop land-use systems of Akok area. $\mathrm{N}$ fertilization could be added according to crop requirements (Table 3.)

\section{Recommendation}

A cheap alternative for the farmers of Akok is the use of wood ash, which is widely available and considered as waste by the wood industries established in the forest zone of Cameroon. Since the government stopped subsidizing the use of commercial fertilizers and amendments, the use of wood ash, is a justified option, as no farmers have no access to financial credit. Ash is a good source of $\mathrm{Ca}$, K, P and Mg (Etiegni and Campbell, 1991). Its application in tropical acid soils can help increasing soil $\mathrm{pH}$ and neutralizing $\mathrm{Al}$ toxicity and at the same time it could supply $\mathrm{P}$ and $\mathrm{K}$ (Voundi Nkana et al., 1998).

\section{Conclusion}

The acid soils of Akok are mainly composed of sand and clay. They are poor in organic carbon, total nitrogen and ECEC. The soil nutrients are mainly stored in the topsoil, together with organic matter (normal). Land use significantly affects the sand, the clay and the silt fractions. For agricultural development, utilization of residues from harvests to cover the soil surface, liming and $\mathrm{P}$ fertilization appeared as the first and the most efficient management options. $\mathrm{N}$ and $\mathrm{K}$ fertilizations could be added according to crop requirements. Since farmers cannot afford chemical fertilizers, the use of cheap and locally available wood ash as a liming material and $\mathrm{P}$ and $\mathrm{K}$ supplier can be seen as a promising option that requires further investigations concerning their quality and application doses.

\section{ACKNOWLEDGEMENTS}

The authors are gratifull to IRAD who provided laboratory facilities and allowed the corresponding author to undertake this research. Financial support was granted by WOTRO (The Netherlands) through its Priority Programme on Biodiversity in Disturbed Ecosystem.

\section{REFERENCES}

ASB, 2002. Alternatives to Slash and Burn. Summary report and synthesis of phase II in Cameroon. Nairobi, Kenya.

Birang à Madong, Hauser S, Brussaard L, Norgrove L. 2003. Earthworm surfacecasting activity on slash-and-burn cropped land and in undisturbed Chromolaena odorata and young forest fallow in south Cameroon. Pedobiologia, 47: 811-818.

Birang à Madong. 2004. Soil macrofauna community structure along a gradient of land use intensification in the humid forest zone of southern Cameroon. Tropical Management papers no 56; ISBN 90-6754-783-2.

Bremmer JM, Tabatabai MA. 1972. Use of ammonia electrode for determination of ammonium in Kjeldahl analysis of soils. Determinations in Soil Science and Plant Analysis, 3: 71-80.

Bremmer JM. 1982. Inorganic nitrogen. In Methods of Soil Analysis, Part II $\left(2^{\text {nd }}\right.$ edn), Page AL, Miller RH, Keeney DR (eds). American Society of Agronomy: Madison, Wisconsin, USA.

Table 3: Lime, $\mathrm{P}$ and $\mathrm{K}$ requirements in different land use systems in southern Cameroon.

\begin{tabular}{lcccc}
\hline Land-use system & \multicolumn{2}{c}{$\begin{array}{c}\text { Pime requirement } \\
\left(\mathbf{t ~ h a}^{-\mathbf{1}}\right)\end{array}$} & $\begin{array}{c}\text { P requirement } \\
\left(\mathbf{k g ~ h a}^{\mathbf{- 1}}\right)\end{array}$ & $\begin{array}{c}\text { K requirement } \\
\left(\mathbf{k g ~ h a}^{\mathbf{- 1}}\right)\end{array}$ \\
\hline Sfor & $\mathrm{CaCO}_{3}$ & $\mathrm{CaO}$ & & \\
Cocoa & $5.60 \mathrm{a}$ & $3.14 \mathrm{a}$ & $-2 \mathrm{a}$ & $13 \mathrm{ba}$ \\
Yfor & $0.43 \mathrm{~d}$ & $0.24 \mathrm{~d}$ & $77 \mathrm{a}$ & $16 \mathrm{a}$ \\
$\mathrm{Chro}$ & $3.01 \mathrm{c}$ & $1.69 \mathrm{c}$ & $14 \mathrm{a}$ & $10 \mathrm{bc}$ \\
$\mathrm{Crop}$ & $3.27 \mathrm{cb}$ & $1.83 \mathrm{cb}$ & $78 \mathrm{a}$ & $9 \mathrm{c}$ \\
$\mathrm{P}$ & $3.92 \mathrm{~b}$ & $2.19 \mathrm{~b}$ & $69 \mathrm{a}$ & $12 \mathrm{bc}$ \\
\hline \multicolumn{4}{c}{ Note: Figures with the same letter within a column are not significantly different at 5\% level of significance. }
\end{tabular}


Buol SW, Sanchez PA, Cate RBJr, Granger MA. 1975. Soil fertility capability classification. A technical soil classification system of soil fertility management. In Soil Management in Tropical America, Bornemisza E, Alvarado A (eds). 126-145 North Carolina University, Raleigh, NC.

Dabin B. 1984. Les sols acides tropicaux. Cahiers ORSTOM, Série Pédologie, 21: 7-19.

Duchaufour P. 1960. Précis de Pédologie. Masson \& $C^{\text {ie }}, 120$ Boulevard SaintGermain - Paris $\left(\mathrm{VI}^{\mathrm{e}}\right) ; 419$.

Etiegni L, Campbell AG. 1991. Physical and Chemical characteristics of ash wood. Boresource Technology, 37: 173-178.

Gee GW, Bauder JW. 1986. Particle size analysis. In Methods of soil analysis, Part I ( $2^{\text {nd }}$ edn), Klute A (ed). Agronomy Monograph No. 9. American Society of Agronomy: Madison, WI; 383-411.

Hearnes DL. 1984. Determination of organic carbon in soils by an improved chromic acid digestion and spectro-photometric procedure. Communications in Soil Science and Plant Analysis, 15: 11911213.

Joran CF. 1985. Nutrient Cycling in Tropical Forest Ecosystems. Wiley: New York, USA.

Juo ASR, Manu A. 1996. Chemical dynamics in slash-and-burn agriculture. Agriculture, Ecosystems and Environment, 58: 49-60.

Kamprath EJ. 1970. Exchangeable aluminum as a criterion for liming leached mineral soils. Soil Science Society of America Proceedings, 24: 252-254.

Kanmegne J. 2004. Slash and burn agriculture in the humid zone of southern Cameroon: soil quality dynamics, improved fallow management and farmers'perception. Ph.D thesis, Wageningen University, The Netherlands, p. 184.

Kauffmann S, Sombrooek W, Mantel S. 1998. Soils of rainforests: characterization and major constraints of dominant forest soils in the humid tropics. In Soils of Tropical Forest Ecosystems: Characteristics, Ecology and Management, Schulte A, Ruhiyat D (eds). Springer-Verlag: Berlin; 9-20.
Lal R. 1996. Deforestation and land-use effects on soil degradation and rehabilitation in Western Nigeria. I. Soil physical and hydrological properties. Land Degradation \& Development, 7: 1945.

Landon JR. 1991. Booker Tropical Soil Manual: A handbook for Soil Survey and Agricultural Land Evaluation in the Tropics and Subtropics (Paperback edn). Longman Science and Technology: Harlow, England.

Leplaideur A. 1985. Les systèmes agricoles en zone forestière. Les paysans du Centre et du Sud-Cameroun. IRAT, Yaoundé.

Liebhardt WC. 1981. The basic saturation concept and lime and potassium recommendations on Delaware's coastal plain soils. Soil Science Society of America Journal, 45: 544-549.

Mehlich M. 1984. Mehlich 3 soil test extractant: a modification of the Mehlich 2 extractant. Communications in Soil Science and Plant Plant Analysis, 15: 1409-1416.

Menzies NW, Gillman GP. 1997. Chemical characterization of soils of a tropical humid forest zone: a methodology. Soil Science Society of America Journal, 61: 1355-1363.

Motomizu S, Wakimoto P, Toei K. 1983. Spectrophotometric determination of phosphate in river waters with molybdate and malachite green. Analyst, 108: 361367.

Sanchez PA, Couto W, Buol SW. 1982. The fertility applicability and modification. Geoderma, 27: 283-309.

SAS. 1999. The SAS system. Versiom 8 for windowa. SAS Institute Inc. Nashville Enabled. Cary. NY.

Shipper LA, Sparling GP. 2000. Performance of soil condition indicators across taxonomic groups and land uses. Soil Science Society of America Journal, 64: 300-311.

Shepherd G, Bureh R, Gregory PJ. 2000. Land use affects the distribution of soil inorganic nitrogen in small-holder production systems in Kenya. Biology and Fertility of Soils, 31: 348-355.

Tchienkoua M, Zech W. 2004. Organic carbon and plant nutrient dynamics under three land uses in the highlands of West 
Cameroon. Agriculture, Ecosystems and Environment, 104: 673-679.

Tchienkoua. 2005. Quantitative assessment of soil processes and land use systems in the humid zone of southern Cameroon. PhD thesis, Universität Bayreuth, Germany.

Tulaphitak T, Pairintra C, Kyuma K. 1985. Changes in soil fertility and soil tilth under shifting cultivation. 2: changes in soil nutrient status. Plant and Soil, 31: 239-249.

USDA. 1986. Amendments to Soil Taxonomy. Oart 615 (430-VI-NSTH). INCOMLAC. Soil Conservation Service, Washington, DC.

Voundi Nkana JC, Demeyer A, Baert G, Verloo MG, Van Ranst E. 1997. Chemical fertility aspects influenced by the mineralogical composition of some acid tropical soils of the forest zone in
Central Cameroon. Agrochimica, 41: 209220.

Voundi Nkana JC, Demeyer A, Verloo MG. 1998. Chemical effects of wood ash on plant growth in tropical acid soils. Bioresource Technology, 63: 251-260.

Voundi Nkana JC, Tonye J. 2002. Assessment of certain soil properties related to different land-use systems in the Kaya watershed of the humid forest zone of Cameroon. Land Degradation and Development. Published online in Wiley Inter Science (www.interscience. wiley.com). DOI: 10.1002/ldr.519

Yemefack M. 2005. Modeling and monitoring soil land use dynamics within shifting agricultural landscape mosaic system in southern Cameroon. ITC Dissertation 121, ITC Enschede and Utrecht University, The Netherlands; ISBN 906164-233-7. 